\title{
Impacts of the eastern route of the South-to-North Water Diversion Project emergency operation on flooding and drainage in water-receiving areas: an empirical case in China
}

\author{
Kun Wang ${ }^{1,2}$, Zongzhi Wang ${ }^{2}$, Kelin Liu ${ }^{2}$, Liang Cheng ${ }^{2}$, Lihui Wang ${ }^{3}$, and Ailing $\mathrm{Ye}^{2,3}$ \\ ${ }^{1}$ College of water Conservancy and Hydropower Engineering, Hohai University, Nanjing 210098, China \\ ${ }^{2}$ State Key Laboratory of Hydrology-Water Resources and Hydraulic Engineering, \\ Nanjing Hydraulic Research Institute, Nanjing 210029, China \\ ${ }^{3}$ College of Civil Engineering, Fuzhou University, Fuzhou 350002, China
}

Correspondence: Zongzhi Wang (wangzz77@163.com)

Received: 18 July 2018 - Discussion started: 13 September 2018

Revised: 25 January 2019 - Accepted: 26 February 2019 - Published: 19 March 2019

\begin{abstract}
The water levels of lakes along the eastern route of the South-to-North Water Diversion Project (ER-SNWDP) are expected to rise significantly and subsequently affect the processes of flood control and drainage in corresponding lake basins. However, few studies have focused on the impacts of inter-basin water diversion on the flood control and drainage of water-receiving areas at the lake basin scale. Using MIKE software, this paper builds a coupled hydrodynamic model to address the existing literature gap regarding the impacts of inter-basin water diversion on the processes of flood control and drainage in a water-receiving lake basin, and it considers the many types of hydraulic structures in the model. First, a flood simulation model was constructed to simulate the complex movement of water transferred by the ER-SNWDP, by waterlogging in the lakeside area around Nansi Lake (NL), and water in NL and its tributaries. The ER-SNWDP was also considered in the model. Second, the model was calibrated and verified with measurement data, and the results showed that the model was efficient and presented a NashSutcliffe efficiency coefficient (NSE) between 0.65 and 0.99 . Third, the processes of flooding and draining in the lakeside area of NL were simulated under different water diversion and precipitation values. Finally, the impacts of the emergency operations of the ER-SNWDP on flood control and waterlogging drainage in the lakeside area of NL were analysed based on the results from the proposed model, and some implications are presented for the integrated management of inter-basin water diversion and affected lakes.
\end{abstract}

\section{Introduction}

Inter-basin water diversion is a useful approach to solving the spatial unevenness of water resources; however, it makes the water cycle of the water-receiving area more complicated and brings a great challenge to the integrated water management of the water-receiving area and water diversion project (Matete and Hassan, 2006; Webber et al., 2017). The key to the long-term healthy operation of the inter-basin water transfer project is to clarify the influence of inter-basin water transfer on the water-receiving area. In recent decades, several authors have revealed and discussed the impacts of interbasin water transfer on water-receiving areas from many perspectives, which mainly include water quality, water resources, and water ecosystems, and some suggestions regarding the scientific management of water-receiving areas and the water diversion project were proposed (Cole et al., 2011; Emanuel et al., 2015; Zhuang, 2016). A large quantity of transferred water not only changes the water quality, water environment, and other hydrological characteristics of water-receiving areas, but also impacts flood control and waterlogging drainage in some water-receiving areas (Gupta and Zaag, 2008; Liang et al., 2012). Flooding and waterlogging are two of the main natural disasters in terms of losses of human life and economic damage, and flood control and drainage are the top priorities of watershed management (Arrighi et al., 2013; He et al., 2018). However, to the best of our knowledge, there are very few studies on the impacts of 
inter-basin water transfer on flood control and drainage in water-receiving areas from a watershed perspective.

The eastern route of the South-to-North Water Diversion Project (ER-SNWDP) links Gaoyou Lake, Hongze Lake, Luoma Lake, Nansi Lake (NL), and Dongping Lake with 13 pump stations that transfer water from downstream of the Yangtze River to the Huang-Huai-Hai Plain and Shandong Peninsula (Fig. 1a and b). According to the comprehensive plan of the SNWDP, (1) the first planning phase (before 2030) of the eastern route is designed to transfer 8.9 billion $\mathrm{m}^{3}$ of water annually, and approximately 7 billion $\mathrm{m}^{3}$ is expected to be consumed in the above five lake basins and route; (2) the water diversion period covers the non-flood season (October to the following May), and the water diversion ceases for the rest of the time $\mathrm{Bu}-$ reau of South to North Water Transfer of Planning, Designing and Management, Ministry of Water Resources, 2003). Lake basins along the ER-SNWDP, which are also called water-receiving areas for large quantities of water, are consumed in these basins during the water transfer period. As water-receiving areas and transmitting channels of the ERSNWDP, these five lakes are used to store and regulate water resources, and the water levels of the five lakes are significantly increased when the project is operating. The increased lake level impedes flood control and waterlogging drainage in the water-receiving lake basin, especially in low-lying lake basins.

In addition, Shandong Peninsula has suffered from severe drought and the water supply cannot meet the water demand even in the flood season (June to October) for 4 consecutive years since the eastern route began operation in 2013. Emergency water diversion (i.e., water transfer through the water diversion project in flood seasons to alleviate water shortages in water-receiving areas) has been performed many times to supply water to Shandong Peninsula. Furthermore, considering the rigorous demand for water resources caused by rapid socio-economic development, more frequent water transfers are expected in the flood season (June to October) (Guo et al., 2018). Meanwhile, extreme rainfall events caused by climate changes have increased in eastern China (R. Liu et al., 2015). Thus, the probability of rainstorms during the water diversion period in these lake basins will increase. To strengthen the scientific scheduling of flood control projects in waterreceiving areas and water diversion projects, it is necessary to clarify the influence law of water diversion on flood control and drainage in these lake basins.

Based on data availability and regional distribution, the NL Basin (NLB), which is a flood-prone area, was chosen as the research area in this study (Fig. 2). The reason why we chose the NLB is that NL is an important storage node of the ER-SNWDP, as NL is the largest freshwater lake in northern China and has the largest water storage capacity among the lakes along the ER-SNWDP (Zhang, 2009). In addition, the NLB has a history of frequent flooding and waterlogging disasters due to the low drainage capacity in the geomorphic low-lying area around NL (i.e., lakeside area). NL is a storage pond of the ER-SNWDP, the flow of water transferred into NL is $200 \mathrm{~m}^{3} \mathrm{~s}^{-1}$, and the outflow is $100 \mathrm{~m}^{3} \mathrm{~s}^{-1}$. According to the overall plan of the SNWDP, the water level of the upper lake is expected to rise by $50 \mathrm{~cm}$, and that of the lower lake is expected to rise by $70 \mathrm{~cm}$ during the project operation period. A large amount of water diversion has a significant impact on the hydrological situation of NL. The impacts have instigated several studies that aimed to understand the ER-SNWDP effect on the NLB, mainly focusing on environmental and water resource management (Ma et al., 2006; Wu et al., 2011; Zhang, 2009; Zhao et al., 2017). The lake level increased by the ER-SNWDP will decrease the drainage efficiency of pump stations, hinder the flood discharge of rivers in the lakeside area, and then influence the flood control and waterlogging drainage of the NLB. However, the impacts of water diversion on flood control and waterlogging drainage in the NLB are relatively unexplored. A gap in assessing the impacts of inter-basin water diversion on flood inundation in the NLB still exists. An integrated model that could explicitly simulate the impacts of water transfer project operation on the spatiotemporal aspects of inundation is one of the necessary tools that can help bridge this gap.

This study aims to bridge the knowledge gap on the impacts of water diversion by the ER-SNWDP on flood control and inundation in the NLB. For this purpose, the following were set as the two main objectives of this study: (1) to develop one-dimensional and two-dimensional hydrodynamic models that can simulate both the ER-SNWDP operations and its impacts on the flooding and waterlogging processes within the NLB, and (2) to clarify the impacts of the ERSNWDP on flood control and waterlogging drainage in the NLB under different rainstorm events. More specifically, the following sub-objectives will be addressed in this paper: (1) develop a model that integrates MIKE 11, MIKE 21, and MIKE FLOOD to simulate the flooding and waterlogging processes in the NLB under the condition of emergency water diversion by the ER-SNWDP, (2) validate the adequacy of the model in simulating flooding and waterlogging processes in the NLB, (3) simulate flooding and waterlogging processes with the effects of the water diversion project under rainstorms with different return periods, and (4) perform a detailed analysis of the impacts of the inter-basin water transfer on flood control and waterlogging drainage in NLB.

\section{Literature review}

\subsection{Impacts of inter-basin water diversion on water-receiving regions}

Due to the uneven spatial distribution of water resources and regional socio-economic development, the demand for water in certain regions far exceeds the available water amount, thereby resulting in an increasingly serious imbalance be- 


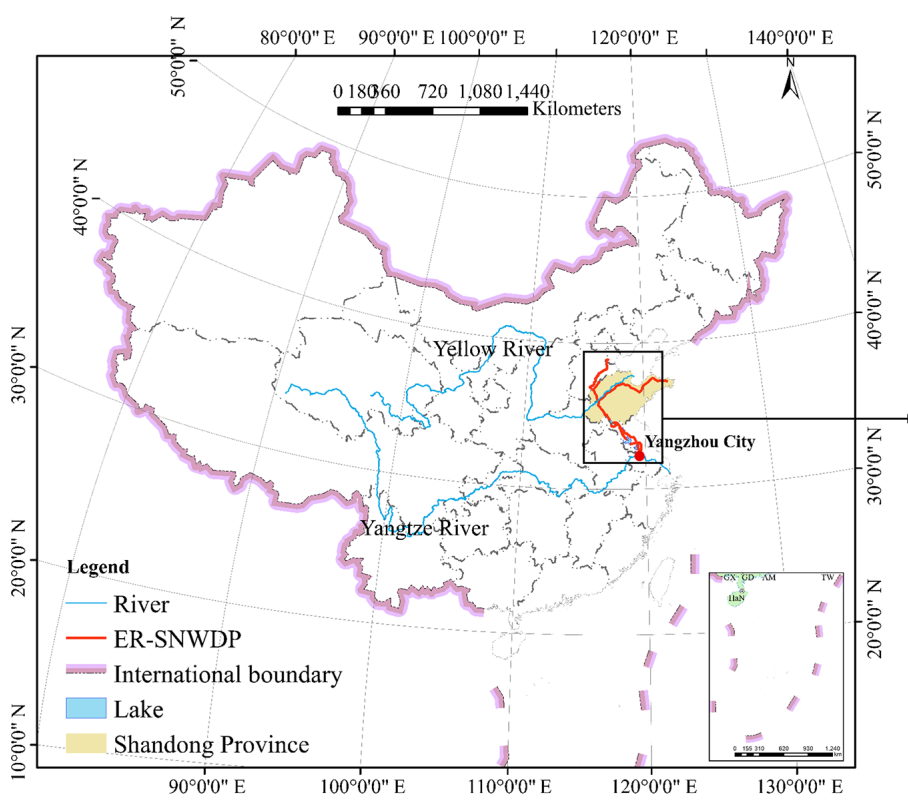

(a)

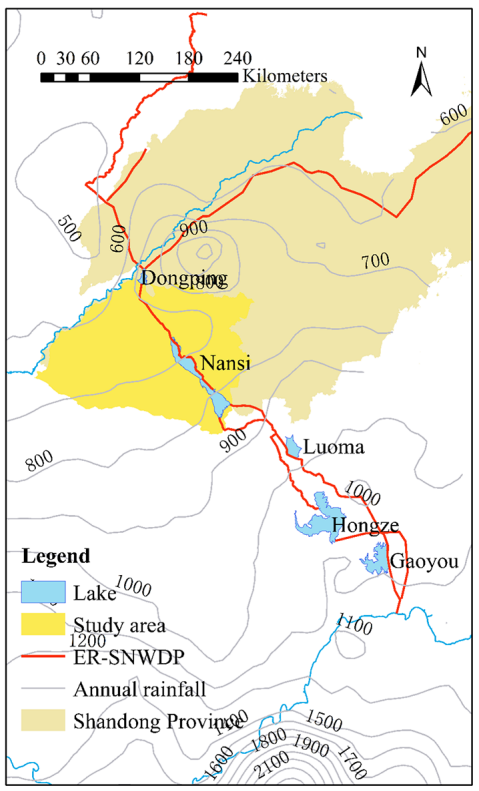

(b)

Figure 1. Sketch of the eastern route of the South-North Water Transfer Project (a). Annual rainfall contours and lakes along the route (b).

tween water demand and supply (Cai and Ringler, 2007; $\mathrm{Hu}$ et al., 2010). As the most effective and direct method of resolving the water resource shortage problem, inter-basin water diversion projects have been widely applied in waterdeficient areas around the world (de Andrade et al., 2011; Wang et al., 2014; Zhang et al., 2015). According to data released by the International Commission on Irrigation \& Drainage (ICID) (2005), the total annual amount of water transferred by water diversion projects around the world is 540 billion $\mathrm{m}^{3}$, which accounts for approximately $14 \%$ of the world's annual water withdrawals. By 2025, annual water diversion is expected to reach 940 billion $\mathrm{m}^{3}$. In water supply and receiving areas, inter-basin water transfer projects significantly affect hydrological elements, such as water quantity, water quality, the water environment, and flood disasters. A full understanding of these impacts is key to the scientific management and long-term operation of inter-basin water diversion and represents the most popular global topic in water resource planning and management research (Aron et al., 1977; Davies et al., 1992; Khan et al., 1999; Liu and Zheng, 2002). Zhang et al. (2015) summarized relevant studies on inter-basin water transfer from 1991 to 2014 and noted that the effects on the hydrological environment caused by China's SNWDP and the corresponding long-term monitoring and protection policy for this project represent the most important current issues.

Current research on the hydrological effects caused by inter-basin water transfer mainly focuses on the following aspects. (1) For groundwater, Kundell (1988) argues that a large amount of imported water significantly increases the amount of available water and directly participates in the wa- ter cycle in water-receiving regions, which has a positive effect on the water environment, groundwater exploitation, and wetland restoration. Relevant studies have indicated that a large amount of imported water can effectively alleviate the problem of decreased groundwater levels and ground subsidence caused by the perennial over-extraction of groundwater in selected areas (Larson et al., 2001; Liu and Zheng, 2002; Wang et al., 2014). Based on a large hydrological distribution model, Ye et al. (2014) evaluated the effect of the middle route of the SNWDP on the groundwater level of the Haihe basin. The results showed that although imported water cannot change the decreasing trend of the groundwater level in the water-receiving area, it can significantly reduce the rate of decrease. (2) Water quality is one of the most important factors underlying the success of inter-basin water transfer projects. Scholars have simulated and evaluated the effects of inter-basin water transfer projects on water quality in water supply and receiving areas. Imported water dilutes the concentration of nutrients, improves the ratio of runoff and pollution in the receiving area, and subsequently improves the water quality. However, inter-basin water transfer projects might also transfer pollutants from the water supply area or river basin along the water diversion line into waterreceiving regions, thus worsening the water quality $(\mathrm{Hu}$ et al., 2008; Karamouz et al., 2010; Tang et al., 2014; Welch et al., 1992; Zhai et al., 2010). The Chicago inter-basin water diversion project, which uses the Lake Michigan basin as its source, has received criticism due to its chronic exposure risk of organic pollutants (Rasmussen et al., 2014). (3) Interbasin water transfer brings water from the water-supply area to the water-receiving area through the water transmission 
channel, which is not conducive to flood control in waterreceiving areas and water transmission channels. Wang et al. (2013) studied the influence of an inter-basin water transfer project on hydraulic parameters during the flood season in a water-supply area. Based on a two-dimensional mathematical model, Sun et al. (2008) used the Anyang River basin, which intersects with the middle route of the SNWTP, as an example to study the influence of the water diversion project on flooding in the river basin that the project passes through. As the storage node of the water diversion project, the large amount of water transferred into the lake significantly changes the interaction law between the water body of the lake basin and the water in the lake tributaries, which subsequently affects the flood control and drainage of the lake basin. However, few quantitative studies have focused on this issue.

\subsection{Simulation of flooding and waterlogging disasters in a basin}

Simulating the flooding and waterlogging processes based on a mathematical model is an important method for analysing flooding and waterlogging characteristics and assessing the flooding and waterlogging disaster risk of a basin; this simulation is also an effective tool for planning the engineering layout of flooding and waterlogging control engineering (Dutta et al., 2015; Q. Liu et al., 2015; Wang et al., 2018). The early flooding and waterlogging simulations of a basin are mainly based on hydrological models, including the Storm Water Management Model (SWMM) (Lee and Heaney, 2003), Model for Urban Storm water Improvement Conceptualisation (MUSIC) (Dotto et al., 2011; Hamel and Fletcher, 2014), Soil and Water Assessment Tool (SWAT) (Dixon and Earls, 2012), and MIKE-SHE (Vrebos et al., 2014), among others. However, hydrological models only simulate the flood-routing process according to the water balance equation and are unable to display the spatial distribution of flood movement. In addition, these models cannot accurately simulate the drainage process of sluice, dam, pumping station, and pipeline hydraulic structures. A hydrodynamic model simulates water routing by solving the SaintVenant equations, which can accurately reflect the movement of water on a plane and in various hydraulic structures. With improvements in computer processing speed and the development of spatial digital elevation information, hydrodynamic models have gradually become an important tool for flood simulations (Moel et al., 2015). Hsu et al. (2000) built a waterlogging simulation model by coupling the SWMM model with a two-dimensional hydrodynamic model and simulated the rainstorm waterlogging in Taipei. Bisht et al. (2016) combined the SWMM with the MIKE URBAN and MIKE 21 models to simulate waterlogging in West Bengal, India. Li et al. (2016) established one-dimensional and two-dimensional coupled hydrodynamic models of Taining County in China based on the MIKEFLOOD model and simulated and analysed the flooding and waterlogging risks in the region. The MIKE 11 and MIKE 21 hydrodynamic models can simulate the influence of a variety of hydraulic structures on the water flow movement process, and the onedimensional and two-dimensional models can describe this coupling in different ways. Therefore, this model has been applied to simulate the flow movement of a variety of water bodies, including rivers, lakes, flood water on the ground, and estuaries (Karim et al., 2016; Quan, 2014; Zolghadr et al., 2010).

\section{Research area and data sources}

\subsection{Research area}

$\mathrm{NL}\left(34^{\circ} 27^{\prime}-35^{\circ} 20^{\prime} \mathrm{N}, 116^{\circ} 34^{\prime}-117^{\circ} 21^{\prime} \mathrm{E}\right)$ is composed of four consecutive lakes (i.e., Nanyang Lake (NY), Dushan Lake, Zhaoyang Lake, and Weishan Lake (WS) - Fig. 2) and is a typical large and shallow lake, with an area of $1266 \mathrm{~km}^{2}$ and an average depth of only $1.5 \mathrm{~m}$ (An and Li, 2009). To manage flooding in this basin, a pivotal project composed of a dam and sluices (Erji Dam - ED) was constructed in the middle of NL, which divides the lake into an upper lake and lower lake. The sluices of the ED control the flood discharge of the upper lake, and the Hanzhuang sluice and Linjia sluice control the flood discharge of the lower lake. The NLB is located in the Yi-Shu-Si River system of the Huaihe River basin, with an area of $31700 \mathrm{~km}^{2}$. The lakeside area refers to the area with a ground elevation (above sea level) below $36.79 \mathrm{~m}$ around the lake, and the ground slope in this area is between 0.0029 and $0.0057^{\circ}$ (Tian et al., 2013; Wang et al., 2010). A total of 53 rivers flow into NL, and 11 of them have a drainage area greater than $1000 \mathrm{~km}^{2}$. Due to the low height and gentle slope of the riverbed, the rivers in the lakeside area have strong interactions with NL. Flood control embankments have been built on both sides of the main inflow channels and around NL to prevent flooding from entering the lakeside area. Due to the low-lying terrain and the construction of flood control embankments, waterlogging in lakeside areas cannot drain into rivers and NL. The waterlogged water in the lakeside area is mainly pumped into rivers and NL through pumping stations. However, the existing pumping stations in this region cannot resist rainstorm waterlogging every 5 years, and some pumping stations cannot resist rainstorm waterlogging every 3 years. When encountering heavy rainstorms, the water cannot be discharged in time; therefore, the NLB is historically known as a floodprone area.

The ER-SNWDP transfers water from Yangzhou to NL and is divided into two sections in the NLB: water entering the lower lake at the Hanzhuang sluice (HS) and the Linjia dam sluice (LS). A pumping station was built at the secondary dam to lift water from the lower lake to the upper lake. The Changgou pumping station is built $24 \mathrm{~km}$ south of 


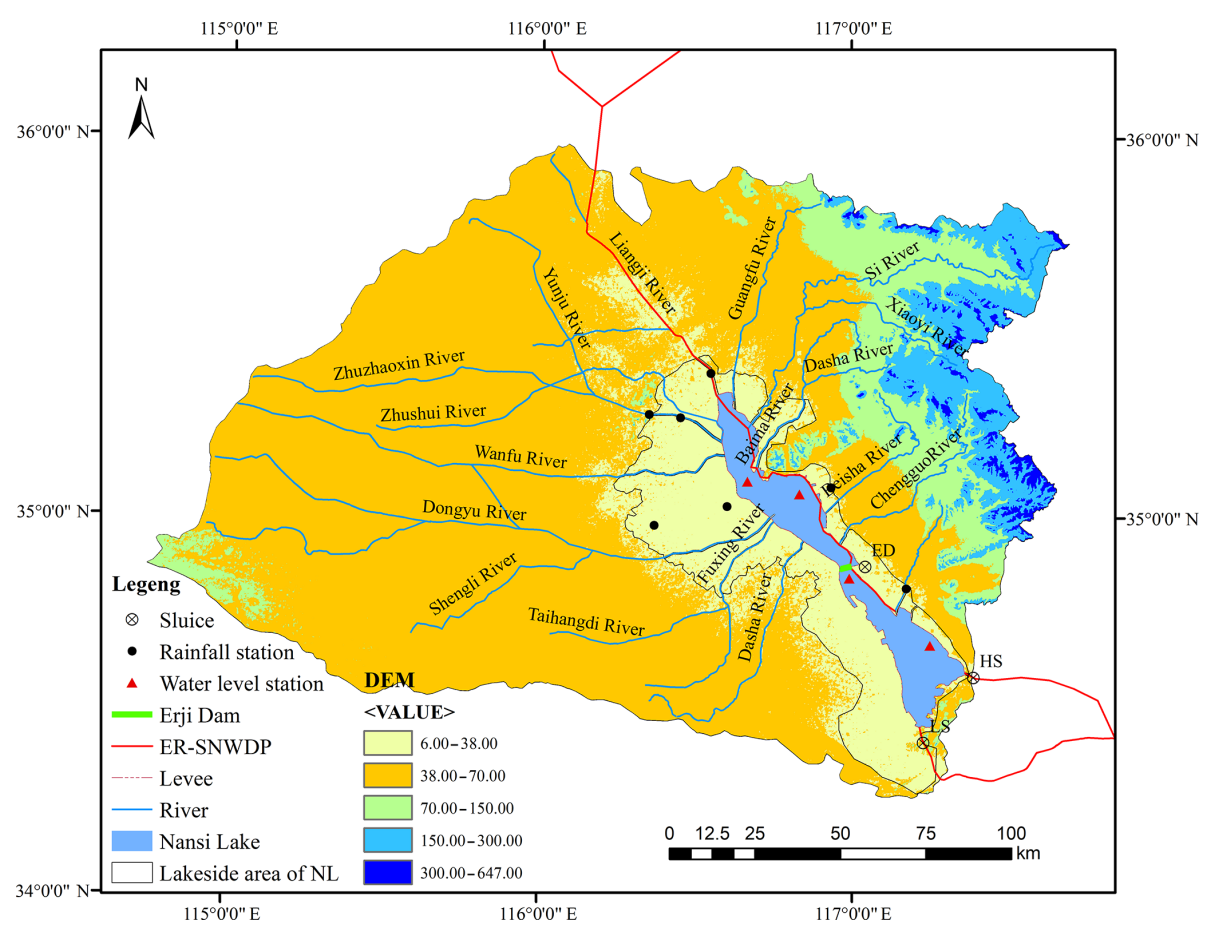

Figure 2. Location of the study area, with the positions of the rainfall and water level gauges, rivers, and hydraulic projects considered in the river system and a topographic map of the NLB. The area surrounded by the black line is the lakeside area, which is defined according to the suggestion of the Planning and Design Institute of the Huaihe Basin Hydraulic Management Bureau in Shandong Province, China.

the Liangji River estuary in the upper lake to transfer water to Shandong Peninsula. According to the first phase planning of the ER-SNWDP, the discharge that enters the lower lake is $200 \mathrm{~m}^{3} \mathrm{~s}^{-1}$, and $5 / 8$ of this amount is pumped into the upper lake. When the water diversion project is running, the water level (with respect to mean sea level) of the lower lake reaches $32.8 \mathrm{~m}$, which is $0.70 \mathrm{~m}$ higher than the mean annual water level. The project transfers water from the upper lake to the north at a flow rate of $100 \mathrm{~m}^{3} \mathrm{~s}^{-1}$. The water level of the upper lake maintains a normal storage level of $34 \mathrm{~m}$, which is $0.48 \mathrm{~m}$ higher than the mean annual water level.

\subsection{Data sources}

The data sources for this study include terrain, hydrological, meteorological, and hydraulic engineering data from the NLB and the engineering layout and operation data of the ER-SNWDP. (1) The digital elevation model (DEM) and river channel bathymetry were supplied by the Planning and Design Institute of the Huaihe Basin Hydraulic Management Bureau in Shandong Province, China. The lakeside area of NL is also provided by the Planning and Design Institute. The DEM of the lakeside area and NL in 2013 was derived from 1:7000 topographic maps, and the river channel bathymetry of all rivers simulated in the one-dimensional model was reflected by 550 cross sections separated at distances between 500 and $1000 \mathrm{~m}$. (2) The hydrological data originated from the Shandong Provincial Hydrology $\mathrm{Bu}-$ reau. These data mainly include the discharge processes of typical floods in the upper boundaries of the rivers and daily rainfall records at six rainfall stations: Huayu (HY), Liangshanzha (LSZ), Wanglu (WL), Wanggudui (WGD), Wangzhong (WZ), and Xuecheng (XC). Each station has daily precipitation records covering approximately 30 to 50 years. The daily water level records of four stations (NY, Makou (MK), ED, and WS; shown in Fig. 2), were also supplied. (3) The meteorological data were downloaded from the National Meteorological Scientific Data Sharing Service Platform (http://data.cma.cn/, last access: 10 December 2018), and the data include the daily records of numerous meteorological parameters, including the wind field and evapotranspiration information. (4) The hydraulic engineering data, including the technical parameters of sluices, pumping stations, and levees in the NLB, were supplied by the Planning and Design Institute of the Huaihe Basin Hydraulic Management Bureau in Shandong Province, China. These data include the location and drainage capabilities of the pump stations, the locations and sizes of the flood control embankments, and the hydraulic parameters of the sluices. (5) The engineering data of the ER-SNWDP were supplied by the Planning and Design Institute of the Huaihe Basin Hydraulic Management Bureau in Shandong Province, China. 


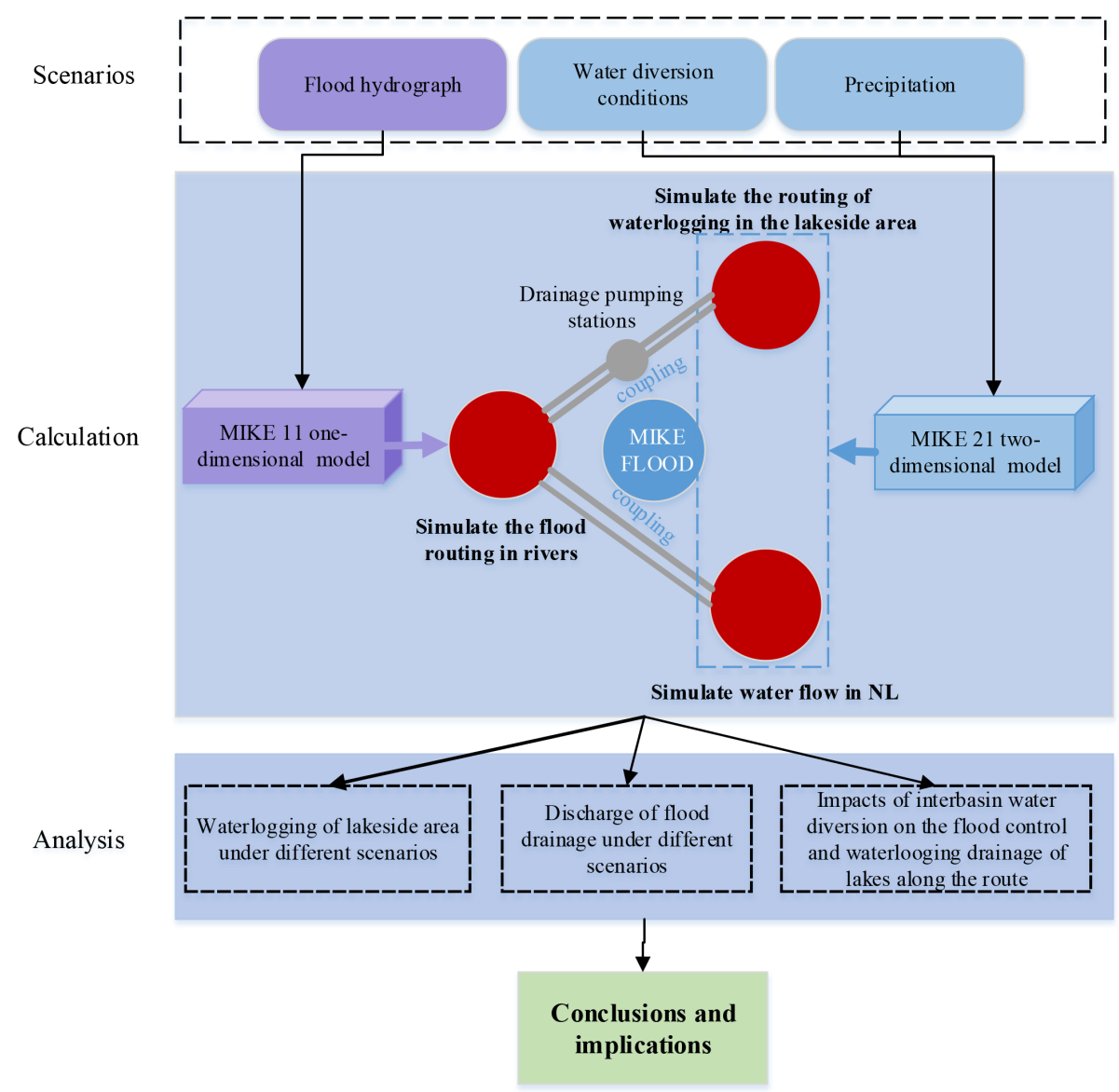

Figure 3. Research framework of the inter-basin water diversion influence on the flood control and waterlogging drainage of lakes along the route.

\section{Methodology}

\subsection{Research framework}

To quantitatively study the impact of the water diversion project on flood control and drainage in the NLB, a hydrodynamic model of waterlogging in lakeside areas of NL was constructed based on MIKE software with consideration of the ER-SNWDP. This model includes a one-dimensional model to simulate flood routing in the river that flows into NL (MIKE 11) and a two-dimensional model to simulate the evolution of plane flow in the lakeside area of $\mathrm{NL}$ (MIKE 21). Different hydraulic structures are set up in the model to simulate the flood control and drainage processes of sluices, dams, pumps, and other hydraulic structures in the research area and the water lifting process of the ERSNWDP pumping station. Coupling of the one-dimensional and two-dimensional models is performed by reasonable links to reflect the interaction among NL, tributary rivers, and the lakeside area. The established model is used to simulate the waterlogging process in the lakeside area under different scenarios. According to the results of the calculation, the influence law of the SNWDP on waterlogging in the lakeside area of NL is analysed. Finally, related suggestions for balancing the water diversion and waterlogging risk are proposed. Figure 3 illustrates the research framework of this paper.

\subsection{One-dimensional hydrodynamic model of the river network}

A total of 53 tributary rivers are located around NL, and they represent the key to studying the influence of water diversion on waterlogging in the lakeside area for accurately simulating the flood evolution and interaction between flood evolution and the high water level of NL. Therefore, a onedimensional mathematical model (MIKE 11) was used to simulate flood routing. The control equation of the model is the Saint-Venant equation (Abbott, 1979), which is composed of a continuity equation and momentum equation.

Continuity equation:

$$
B=\frac{\partial Z}{\partial T}+\frac{\partial Q}{\partial x}=q .
$$


Momentum equation:

$\frac{\partial Q}{\partial t}+\frac{\partial}{\partial X}\left(\frac{\alpha Q^{2}}{A}\right)+g A \frac{\partial z}{\partial x}+\frac{g Q|Q|}{C^{2} A R}=0$,

where $x$ and $t$ denote the spatial and temporal coordinates, respectively; $A$ represents the cross-sectional area; $Q$ and $z$ denote the discharge and water level of the cross section, respectively; $q$ represents the lateral inflow; $R$ represents the hydraulic radius; $C$ represents the Chezy coefficient; $a$ represents the momentum correction factor; and $g$ denotes the gravitational acceleration. The Abbott-Ionescu 6 implicit difference method is used to solve the equation.

First, we generalized the river network by considering the data and computational efficiency. This river network primarily contains 11 rivers, with drainage areas greater than $1000 \mathrm{~km}^{2}$. A total of 550 cross sections were input into the river network model to reflect the changes in river topography, with adjacent sections spaced approximately $1000 \mathrm{~m}$ apart. We generalized the drainage pump stations in the lakeside area of NL. A total of 1000 draining pump stations are used to drain waterlogged water from the lakeside area to rivers and NL, and the model generalized the pump stations according to the distribution of each pump station on both sides of the rivers. The basic principle is to ensure that the total drainage discharge remains the same, with the generalized pumping stations along both sides of the river evenly distributed for a total of 41 generalized pumping stations. Finally, the boundary conditions of the model were set. The upper boundary of the model inputs a discharge hydrograph of the upstream hydrological station of each river. As the lower boundary, the water level of the estuary is based on $\mathrm{NL}$, which is simulated by the two-dimensional model.

\subsection{Two-dimensional hydrodynamic model of NL and the lakeside area}

The MIKE 21 hydrodynamic model was used to simulate the water movement in NL and the waterlogging evolution in the lakeside area. The model area includes NL and the lakeside area around the lake (Fig. 2). Because the one-dimensional model is adopted to simulate the rivers around the lake, the area of the rivers is removed from the two-dimensional model. The two-dimensional model is based on the Reynolds average stress equation of a three-dimensional incompressible fluid, which is subject to the Boussinesq hypothesis and the hydrostatic pressure hypothesis (Boussinesq, 1872), and the control equations used in this model are given as follows.

Continuity equation:

$$
\frac{\partial h}{\partial t}+\frac{\partial h \bar{u}}{\partial x}+\frac{\partial h \bar{v}}{\partial y}=h S
$$

Momentum equation in the $x$ direction:

$$
\begin{aligned}
\frac{\partial h \bar{u}}{\partial t}+\frac{\partial h \bar{u}^{2}}{\partial x}+\frac{\partial h \bar{v}}{\partial y} & =f \bar{v} h-g h \frac{\partial \eta}{\partial x}-\frac{h}{\rho_{0}} \frac{\partial p_{\mathrm{a}}}{\partial x}-\frac{g h^{2}}{2 \rho_{0}} \frac{\partial \rho}{\partial x} \\
& +\frac{\tau_{s x}}{\rho_{0}}-\frac{\tau_{b x}}{\rho_{0}}-\frac{1}{\rho}\left(\frac{\partial s_{x x}}{\partial x}+\frac{\partial s_{x y}}{\partial x}\right) \\
& +\frac{\partial}{\partial x}\left(h T_{x x}\right)+\frac{\partial}{\partial x}\left(h T_{x y}\right)+h u_{\mathrm{s}} S .
\end{aligned}
$$

Momentum equation in the $y$ direction:

$$
\begin{aligned}
\frac{\partial h \bar{v}}{\partial t}+\frac{\partial h \bar{v}^{2}}{\partial y}+\frac{\partial h \bar{u} v}{\partial x} & =f \bar{u} h-g h \frac{\partial \eta}{\partial y}-\frac{h}{\rho_{0}} \frac{\partial p_{\mathrm{a}}}{\partial y}-\frac{g h^{2}}{2 \rho_{0}} \frac{\partial \rho}{\partial y} \\
& +\frac{\tau_{s y}}{\rho_{0}}-\frac{\tau_{b y}}{\rho_{0}}-\frac{1}{\rho_{0}}\left(\frac{\partial s_{y x}}{\partial y}+\frac{\partial s_{y y}}{\partial x}\right) \\
& +\frac{\partial}{\partial x}\left(h T_{x y}\right)+\frac{\partial}{\partial y}\left(h T_{y y}\right)+h v_{\mathrm{s}} S,
\end{aligned}
$$

where $x, y$, and $z$ are Cartesian coordinates; $t$ denotes the temporal coordinates; $\eta$ represents the bottom elevation of the river; $d$ represents the depth of the water; $h=d+\eta$ represents the total head of the water; $u, v$, and $w$ represent the velocity components in the $x, y$, and $z$ directions, respectively; $p_{\mathrm{a}}$ represents the local atmospheric pressure; $\rho$ represents the density of water; $\rho_{0}$ represents the reference water density; $f=2 \Omega \sin \phi$ represents a Coriolis parameter; $f \bar{v}$ and $f \bar{u}$ represent the acceleration caused by the Earth's rotation; $S_{x x}, S_{x y}, S_{y x}$, and $S_{y y}$ represent the components of the radiation stress tensor; $T_{x x}, T_{x y}, T_{y x}$, and $T_{y y}$ represent the horizontal viscous stresses; $S$ represents the magnitude of the discharge due to point sources; and $\left(u_{\mathrm{s}}, v_{\mathrm{s}}\right)$ denotes the velocity by which the water is discharged into the ambient water.

The total area of the two-dimensional model is approximately $4750 \mathrm{~km}^{2}$, including NL $\left(1266 \mathrm{~km}^{2}\right)$, the lakeside area $\left(3696 \mathrm{~km}^{2}\right)$ shown in Fig. 2, and removes the area of the rivers simulated by the one-dimensional model, with both sides of the river embankment and the $36.79 \mathrm{~m}$ contour line as the outer boundaries of the model. Dikes were set up on both sides of the river around NL and at the ED to simulate the flood control effect of levees. Sources were added to simulate the water transfer process of the ER-SNWDP. When the model is running, the rainfall processes of the HY, LSZ, WL, $\mathrm{WGD}, \mathrm{XC}$, and $\mathrm{WZ}$ rainfall stations in the research area are input.

\subsection{Waterlogging simulation model of NL and the lakeside area when considering the SNWDP}

The MIKE FLOOD model is used to couple the onedimensional and two-dimensional models, and the specific process is described as follows. (1) A lateral link is applied 
Table 1. Statistical evaluation of model performance for water level simulations at selected gauging stations for 2007 and 2008 flood events.

\begin{tabular}{lcc}
\hline Gauging station & \multicolumn{2}{c}{ NSE } \\
\cline { 2 - 3 } & 2007 & 2008 \\
\hline Nanyang & 0.72 & 0.65 \\
Makou & 0.69 & 0.76 \\
Erji Lake (downstream) & 0.67 & 0.98 \\
Weishan & 0.82 & 0.99 \\
\hline
\end{tabular}

to connect the lakeside area and the tributaries of NL to simulate the flood exchange between the lakeside area and tributaries, and (2) a standard link is applied to connect the intolake rivers and NL to reflect the influence of the lake level height in blocking the drainage of into-lake rivers. A total of 22 lateral connections and 52 standard connections are present in the coupling model.

\subsection{Calibration and validation of the coupling model}

The model is calibrated and validated using two actual floods that occurred in July 2007 and July 2008 in the NLB. Figure 4 shows the simulated and measured water levels at four stations: NY, MK, ED, and WS in NL. Overall, the measured water level process shows good agreement with the simulated water level process, and the arrival of the simulated flood peak is consistent with that of the measured data. The Nash-Sutcliffe efficiency (NSE) coefficient, which was proposed by Nash and Sutcliffe (1970), is used to evaluate the coupling model. The NSE for the daily flow varied from 0.67 (ED) to 0.82 (WS) during calibration and from 0.65 (NY) to 0.99 (WS) during verification (Table 1), thus showing good agreement between the observed and simulated water levels. As a result, the calibrated roughness coefficients, $n$, were 0.055 for agricultural fields, 0.08 for residential areas in the lakeside area, and 0.028 for NL.

\section{Results and discussion}

\subsection{Scenario design}

NL is located in China's north-south climate transition zone, and the temporal distribution of rainfall is severely uneven, with rainfall in the flood season accounting for $72 \%$ of the annual precipitation. This basin is located in the north-south climate transition zone of China, and the phenomenon of drought-flood abrupt alternation (DFAA) frequently occurs. DFAA refers to a rainstorm after a long period of drought and can result in severe flood damage. Figure 5 shows the process of rainfall at Wanglu station and the water levels of the upper and lower lakes at NY and WS stations in 2003. Since there was no precipitation in the first half of the year, NL dried up from April to June 2003, which had a devastating impact on the ecosystem of NL. In the future, if the NLB encounters another drought, such as that in 2003, emergency water diversion by the ER-SNWDP will be the first choice to provide ecological water for NL. However, heavy rains occurred after 22 August and caused a steep increase in the water level in NL, and 2003 was a typical year of DFAA. The statistical data show that the waterlogged area of the NLB is $2360 \mathrm{~km}^{2}$, and waterlogging disasters resulted in a great economic loss in the lakeside area. Therefore, we take 2003 as an example to research the impacts of emergency ecological water diversion by the ER-SNWDP on waterlogging in the NLB.

In recent years, water resource shortages have become increasingly intense in Shandong Peninsula, China. Even in the flood season, local water resources still encounter difficulty in meeting demands; thus, the supply of water to the region that relies on the ER-SNWDP is expected to be more frequent.

To analyse the influence of water diversion on waterlogging disasters in the lake basin along the ER-SNWDP, this paper set two conditions in which the ER-SNWDP supplies an emergency transfer of ecological water to NL and Shandong Peninsula. Ecological water refers to the transferred water needed to maintain the normal development and relative stability of all types of ecological systems in NL during the drought period and prevent the recurrence of the dry lake situation that occurred in 2003.

1. An ER-SNWDP emergency requires a supply of ecological water for NL.

Taking a waterlogging occurring in the NLB after 22 August 2003 as an example, the impact of water diversion on the waterlogging process in the NLB was studied. Considering the flood control safety of the NLB, we assume that the emergency water transfer stopped at the beginning of the rainfall event on $22 \mathrm{Au}-$ gust 2003 (Fig. 5). Because the water diversion project is no longer operational during rainfall, the effect of water diversion on the flood process of NL mainly increases the water level of NL. Therefore, two scenarios of waterlogging of the NLB in August 2003 were simulated: the waterlogging process of the NLB under the influence of emergency water transfer in August 2003, which is recorded as scenario 2 , and the waterlogging process without water diversion recorded as scenario 1 (see Table 2 for scenario settings). The difference between scenario 1 and scenario 2 is the initial water level of NL. In scenario 1, the water levels of the upper lake and lower lake are 33.01 and $32.20 \mathrm{~m}$, respectively, as measured on 22 August 2003. In scenario 2, the water levels of the upper lake and lower lake have been raised to 34 and $32.3 \mathrm{~m}$, respectively, by emergency water diversion. The rainfall processes of the two scenarios were measured from 22 August 2003 to 2 September 2003. 

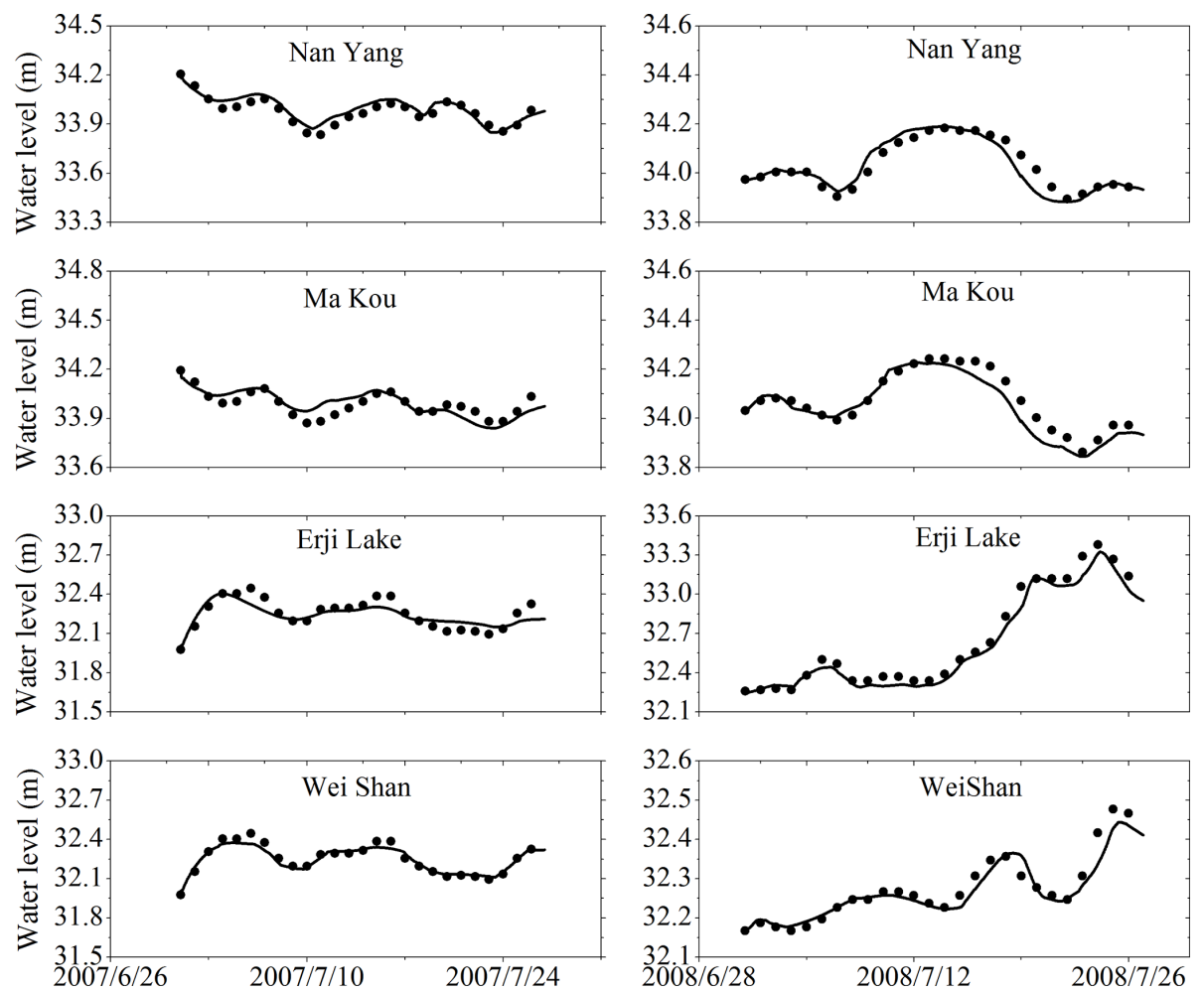

Figure 4. Comparison of the observed and simulated water levels at the selected locations for 2007 flood events under calibration conditions (left) and 2008 events under validation conditions (right). Black dots represent observed data, and black lines represent model simulation results.

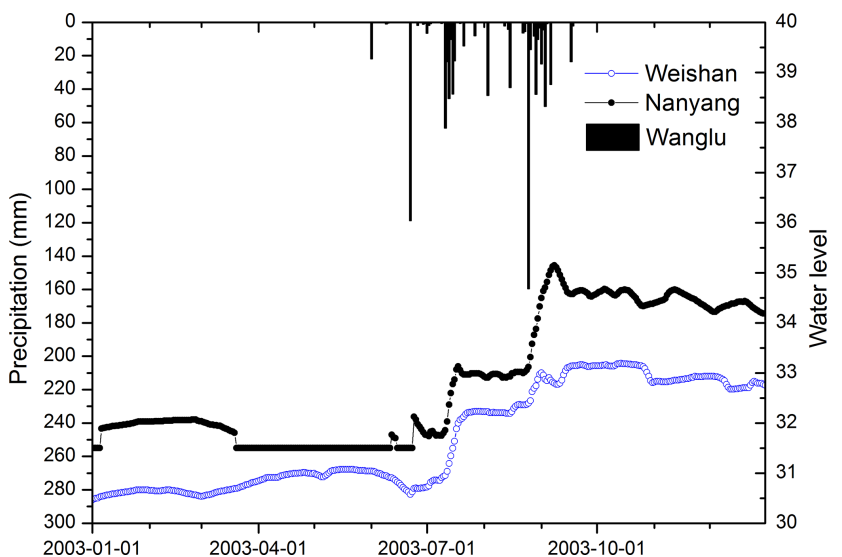

Figure 5. Rainfall at Wanglu station in the NLB and water level variations in the upper lake and lower lake in 2003. The upper lake is dry when the water level of NY is $31.5 \mathrm{~m}$. Before July 2003, the NLB suffered severe drought, but heavy rains in August caused serious floods.

2. An ER-SNWDP emergency requires a supply of water for Shandong Peninsula, China.

Under this condition, the influence of water diversion on waterlogging disasters in the lakeside area of NL under different rainstorm intensities is analysed. The pro- cesses of 3-day designed rainfall events with return periods of 5,10 , and 20 years at six precipitation stations were calculated. Affected by the emergency water diversion, the initial water levels of the upper lake and lower lake were 34.00 and $32.30 \mathrm{~m}$, respectively, in scenarios 6,7 , and 8 . Because the water was transferred to alleviate the water shortage of Shandong Peninsula, China, the ER-SNWDP continued to operate during rainfall events. In contrast, the initial water levels of the upper lake and lower lake were 33.01 and $32.20 \mathrm{~m}$, respectively, as measured on 22 August 2003, in scenarios 3, 4, and 5. In summary, a total of eight simulation scenarios were set up, as shown in Table 2.

\subsection{Impacts of emergency water diversion by the ER-SNWDP on waterlogging of the NLB}

Rice, cotton, corn and soybeans are the main crops in the study region, and their waterlogging tolerance depths are $0.5,0.1,0.1$, and $0.1 \mathrm{~m}$, respectively (Wang, 2015). Therefore, the areas with inundated depths above 0.1 and $0.5 \mathrm{~m}$ are counted in the simulation results. In the calculation results of scenario 1 and scenario 2, the areas with submerged depths larger than 0.1 and $0.5 \mathrm{~m}$ are counted. Table 3 shows the rainfall events from 22 August to 2 September 2003, under the condition of no water diversion, which caused the inundated 
Table 2. Computational scenario setting.

\begin{tabular}{|c|c|c|c|}
\hline Sr. no. & Initial water level of NL & Rainfall & $\begin{array}{l}\text { Whether the } \\
\text { ER-SNWDP } \\
\text { works during } \\
\text { the simulation }\end{array}$ \\
\hline 1 & $\begin{array}{l}33.01 \mathrm{~m} \text { in upper lake, } \\
32.20 \mathrm{~m} \text { in lower lake }\end{array}$ & $\begin{array}{l}\text { Actual daily rainfall } \\
\text { from } 22 \text { August to }\end{array}$ & NO \\
\hline \multirow[t]{2}{*}{2} & $\begin{array}{l}34.0 \mathrm{~m} \text { in upper lake, } 32.3 \mathrm{~m} \text { in } \\
\text { lower lake }\end{array}$ & 2 September 2003 & \\
\hline & & $\begin{array}{l}\text { Designed storm with } \\
\text { return periods of }\end{array}$ & \\
\hline $\begin{array}{l}3 \\
4 \\
5\end{array}$ & $\begin{array}{l}\text { Actual water level on } \\
22 \text { August } 2003\end{array}$ & $\begin{array}{l}5 \text { years } \\
10 \text { years } \\
20 \text { years }\end{array}$ & NO \\
\hline $\begin{array}{l}6 \\
7 \\
8\end{array}$ & $\begin{array}{l}34.0 \mathrm{~m} \text { in upper lake, } \\
32.3 \mathrm{~m} \text { in lower lake }\end{array}$ & $\begin{array}{l}5 \text { years } \\
10 \text { years } \\
20 \text { years }\end{array}$ & YES \\
\hline
\end{tabular}

area in the lakeside region to reach $1126.59 \mathrm{~km}^{2}$, and the area with a submerged depth over $0.5 \mathrm{~m}$ reached $383.68 \mathrm{~km}^{2}$. Statistical data show that the total waterlogging area under the $36.79 \mathrm{~m}$ contour line was $1284.21 \mathrm{~km}^{2}$ in 2003 . The simulation result is slightly smaller than the survey result because the simulation did not cover the entire year, and rain remained in the basin after 2 September 2003. In general, the simulation results can be considered reasonable.

Table 4 shows the increase in the waterlogging area in the lakeside area of NL under the condition of water diversion in the ER-SNWDP compared with that without water diversion. When the phenomenon of DFAA occurs, the lake level increase via the emergency operation of the ER-SNWDP during the flood season increases the waterlogging intensity in the lakeside area of NL. Compared with the situation without water diversion, the area with a submerged depth over $10 \mathrm{~cm}$ increased by $34.26 \mathrm{~km}^{2}$. Emergency water diversion resulted in a relative increase of $0.99 \%$ in the submerged area. The heavy disaster area, with a water depth of more than $50 \mathrm{~cm}$, increased by $51.09 \mathrm{~km}^{2}$, which was $13.32 \%$ higher than that without water diversion.

Figure 6 shows the waterlogging distribution in the lakeside area of NL under two scenarios. The comparison in Fig. $6 \mathrm{a}$ and $\mathrm{b}$ shows that the water diversion primarily increased the waterlogging area between the Dongyu River and Wanfu River in the western region of NL and had a relatively small impact on the eastern area of NL. Compared with the eastern NL, due to the lower and flatter terrain in the western $\mathrm{NL}$, the raised water level of NL has a greater impediment to drainage in the western NL. Therefore, water-receiving lake basins with plain areas should consider the effects of inter-basin water diversion on waterlogging disasters. Figure 7 presents the stage hydrograph for the MK hydrographic station and the flood discharge of the ED for two scenarios.
Figure 7 indicates that emergency water diversion has an obvious influence on the water level of NL during the initial period of rain, and the regulation of the ED junction leads to a decrease in the water level difference between the two scenarios. Emergency water diversion increases the initial water level of NL at the beginning of the rainfall event, and the water level of the upper lake in scenario 2 first reaches the water level at which the ED begins flood drainage. With the increase in the water level, the discharge of the ED also increases, which satisfactorily adjusts the water level of the upper lake. Affected by the higher initial water level raised by water diversion, the flood discharge start time of the ED junction in scenario 2 is 4 days earlier than that in scenario 1 . Furthermore, the total amount of flood discharge in scenario 2 increases by approximately 249 million $\mathrm{m}^{3}$ compared to that in scenario 1 (Fig. 7).

\subsection{Impacts caused by ER-SNWDP emergency water diversion for Shandong Peninsula during waterlogging of the NLB}

Table 5 shows the simulation results of waterlogging in the lakeside area in the case of the diversion and non-diversion of water by the ER-SNWDP to Shandong Peninsula when designed rainfall events with 5-year, 10-year, and 20-year return periods occur in the basin. Emergency water diversion has certain effects on the waterlogged area in the lakeside area of NL. According to the comparison of scenarios 3 and 6 , when the NLB encounters rainfall events with a 5-year return period, the areas with submerged depths over 0.1 and $0.5 \mathrm{~m}$ increase by 22.27 and $26.14 \mathrm{~km}^{2}$, respectively, under the condition of emergency water diversion.

Figure 8 illustrates the relative increase in the waterlogging area and its change trend in the lakeside area of NL 
Table 3. Results of waterlogging in the lakeside area of NL.

\begin{tabular}{lrr|rr|rr}
\hline Sr. no. & \multicolumn{2}{c|}{ Water depth of NL } & \multicolumn{2}{c|}{$\begin{array}{c}\text { Area with an inundated } \\
\text { depth above } 0.1 \mathrm{~m}\end{array}$} & \multicolumn{2}{c}{$\begin{array}{c}\text { Area with an inundated } \\
\text { depth above } 0.5 \mathrm{~m}\end{array}$} \\
\cline { 2 - 7 } & Average (m) & Max (m) & Total area $\left(\mathrm{km}^{2}\right)$ & Area ratio $(\%)$ & Total area $\left(\mathrm{km}^{2}\right)$ & Area ratio $(\%)$ \\
\hline 1 & 2.47 & 5.96 & 1126.59 & 32.51 & 383.68 & 11.07 \\
2 & 2.80 & 6.14 & 1160.85 & 33.50 & 434.77 & 12.55 \\
\hline
\end{tabular}

Table 4. Increment of the waterlogging area in the lakeside area of NL.

\begin{tabular}{lrrr|rrr}
\hline Contrastive analysis & \multicolumn{3}{c|}{$\begin{array}{c}\text { Area with an inundated } \\
\text { depth above } 0.1 \mathrm{~m}\end{array}$} & \multicolumn{3}{c}{$\begin{array}{c}\text { Area with an inundated } \\
\text { depth above 0.5 m }\end{array}$} \\
\cline { 2 - 6 } & $\begin{array}{r}\text { Increment } \\
\left(\mathrm{km}^{2}\right)\end{array}$ & $\begin{array}{r}\text { Relative } \\
\text { increase }(\%)\end{array}$ & $\begin{array}{r}\text { Area ratio } \\
\text { increase }\end{array}$ & $\begin{array}{r}\text { Increment } \\
\left(\mathrm{km}^{2}\right)\end{array}$ & $\begin{array}{r}\text { Relative } \\
\text { increase }(\%)\end{array}$ & $\begin{array}{r}\text { Area ratio } \\
\text { increase }\end{array}$ \\
\hline Variation & 34.26 & 3.04 & 0.99 & 51.09 & 13.32 & 1.47 \\
\hline
\end{tabular}

Table 5. Results of waterlogging simulations of the lakeside area under different scenarios.

\begin{tabular}{lrr|rr|rr}
\hline Sr. no. & \multicolumn{2}{c|}{ Water depth of NL } & \multicolumn{2}{|c|}{ Area with an inundated depth above 0.1 m } & Area with an inundated depth above 0.5 m \\
\cline { 2 - 7 } & Average $(\mathrm{m})$ & Max $(\mathrm{m})$ & Total area $\left(\mathrm{km}^{2}\right)$ & Area ratio (\%) & Total area $\left(\mathrm{km}^{2}\right)$ & Area ratio $(\%)$ \\
\hline 3 & 1.86 & 5.23 & 793.75 & 22.91 & 60.63 & 1.75 \\
4 & 2.03 & 5.87 & 907.85 & 26.20 & 159.98 & 4.62 \\
5 & 2.41 & 6.31 & 1002.05 & 28.92 & 240.54 & 6.94 \\
6 & 2.10 & 5.87 & 816.02 & 23.55 & 86.77 & 2.50 \\
7 & 2.26 & 6.10 & 926.40 & 26.73 & 181.73 & 5.24 \\
8 & 2.17 & 6.08 & 1016.68 & 29.34 & 260.76 & 7.53 \\
\hline
\end{tabular}

under three designed rainfall conditions with water diversion and non-water diversion. Panel (a) shows the contrast of the waterlogged area with an inundated water depth above $0.1 \mathrm{~m}$ under different rainfall events, and panel (b) shows the waterlogged area with an inundated water depth above $0.5 \mathrm{~m}$. The black lines in panels (a) and (b) both show a downward trend, which indicates that the influence of emergency water diversion on waterlogging in the lakeside area decreases with increasing rainfall. Affected by the emergency water diversion, the relative increase in the waterlogging area with an inundated water depth above $0.1 \mathrm{~m}$ is between $1.5 \%$ and $2.8 \%$ (Fig. 8a), and the relative increase in the waterlogging area with an inundated water depth above $0.5 \mathrm{~m}$ is between $8.4 \%$ and $43.1 \%$ (Fig. 8b) when storms with 5-year, 10year, and 20-year return periods occur in the NLB. Under the same rainfall conditions, such as rainstorm events with 5-year return periods, the areal change in submerged water depth greater than $0.5 \mathrm{~m}(43.1 \%)$ in the lakeside area is obviously larger than that of submerged water depth greater than $0.1 \mathrm{~m}(2.8 \%)$. The calculated results indicate that emergency water diversion has more obvious effects on the waterlogging area with deeper $(0.5 \mathrm{~m})$ submerged water.
The emergency water diversion of the SNWDP alleviated the drought situation in the Shandong Peninsula area and increased the degree of waterlogging in the NLB under DFAA. The sluices of the ED are the only flood-discharge channels of the upper lake, and the increased water in the upper lake due to water diversion also increased the task of flood discharge in those sluices. Figure 9 shows the flooddischarge process of the ED project under different design rainfall events. When the NLB encountered a storm with a 5-year return period, the upper lake level did not reach the flood-discharge conditions without the influence of water diversion (Fig. 8a). Affected by water diversion, the sluices began to drain the flood water after $30 \mathrm{~h}$ of rain, with a total discharge volume of 85 million $\mathrm{m}^{3}$ (Fig. 9a). When the NLB encountered a rainstorm with a 10 -year return period, under the condition of water diversion, the sluices began to drain the flood water after $28 \mathrm{~h}$ of rain, which was $36 \mathrm{~h}$ ahead of the situation with no water diversion (at the 66th hour). The total flood volume that was discharged by the ED project was 104 million $\mathrm{m}^{3}$ greater than that without the effect of water diversion (Fig. 9b). When the NLB encountered a storm with a 20-year return period, under the condition of water diversion, the time that the ED project began to discharge the flood 


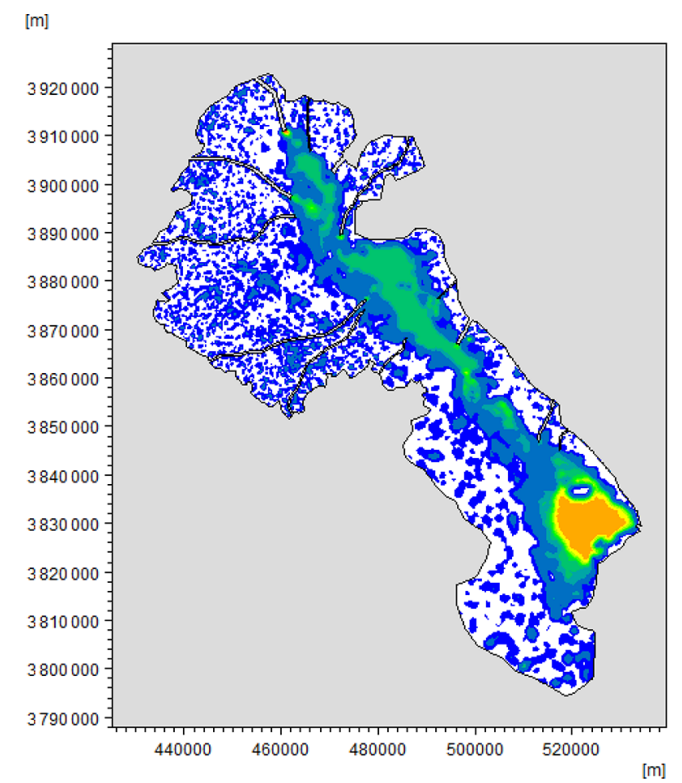

(a) Calculation result of scenario 1
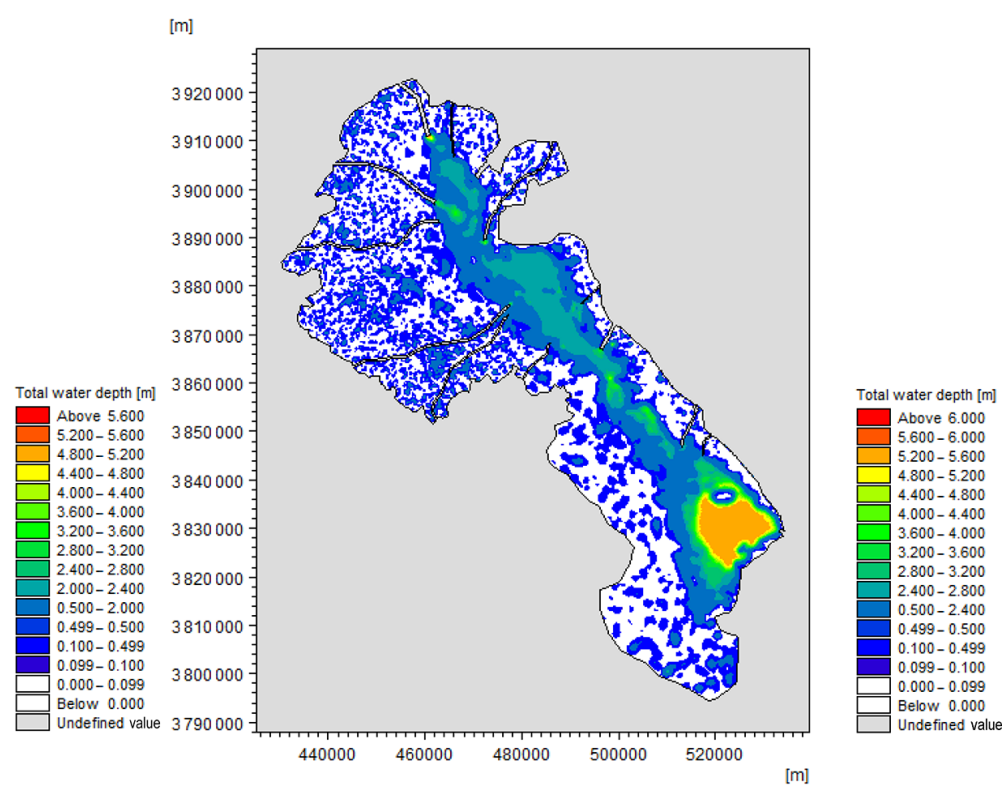

(b) Calculation result of scenario 2

Figure 6. Distribution of waterlogging in the lakeside area of NL.

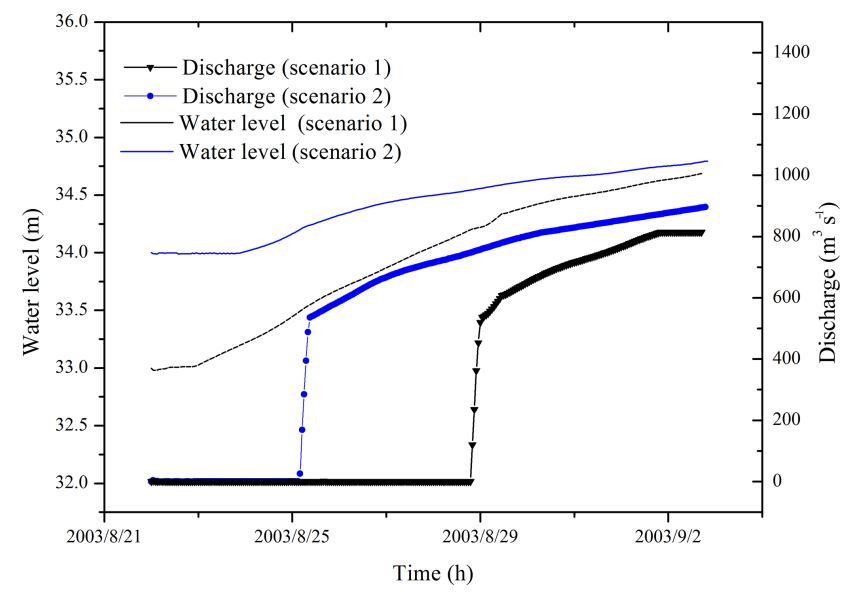

Figure 7. Water level at the MK station in the upper lake and the discharge of flood drainage of the ED from 22 August to 2 September 2003, under scenario 1 (without water diversion) and scenario 2 (with water diversion).

occurred $26 \mathrm{~h}$ after the rain started, which was $32 \mathrm{~h}$ ahead of the situation with no water diversion (at the 58th hour). Compared with the scenario without water diversion, the total discharge volume increased by 129 million $\mathrm{m}^{3}$ (Fig. 9c).

\section{Conclusions and policy implications}

The following selected conclusions are presented.

1. To clarify the impacts that inter-basin water transfer has on the water-receiving areas, this study used the
MIKE model to simulate flooding and waterlogging in the NLB. One- and two-dimensional coupled flooding and waterlogging simulation models of the NLB were established to simulate the water diversion of the ERSNWDP. The MIKE 11 model was applied to simulate the flow movement of water in the water diversion channel and tributaries of NL, and the MIKE 21 model was applied to simulate waterlogging in the lakeside area and water flow in NL. The verification results show that the presented method can effectively simulate the flooding and waterlogging processes in the NLB under the effect of the ER-SNWDP.

2. The ER-SNWDP emergency water transfer to NL increases the risk of waterlogging damage in the lakeside area if it occurs simultaneously with the DFAA. The increased water level caused by water diversion decreases the efficiency of waterlogging drainage, and as a result, the waterlogged area with an inundated water depth above $0.1 \mathrm{~m}$ increased by $0.99 \%$, and that with an inundated water depth above $0.5 \mathrm{~m}$ increased by $13.32 \%$. The flood-discharge time of the ED increased by 4 days, and the total discharge volume increased by 249 million $\mathrm{m}^{3}$ during the simulation.

3. The ER-SNWDP emergency water transfer to Shandong Peninsula raised the water level of NL, which acted as a regulation and storage lake. Compared with the no water transfer situation, the waterlogging areas in the lakeside area increased when NL encountered storms with 5-year, 10-year, and 20-year return periods under water diversion. The calculation results show that 

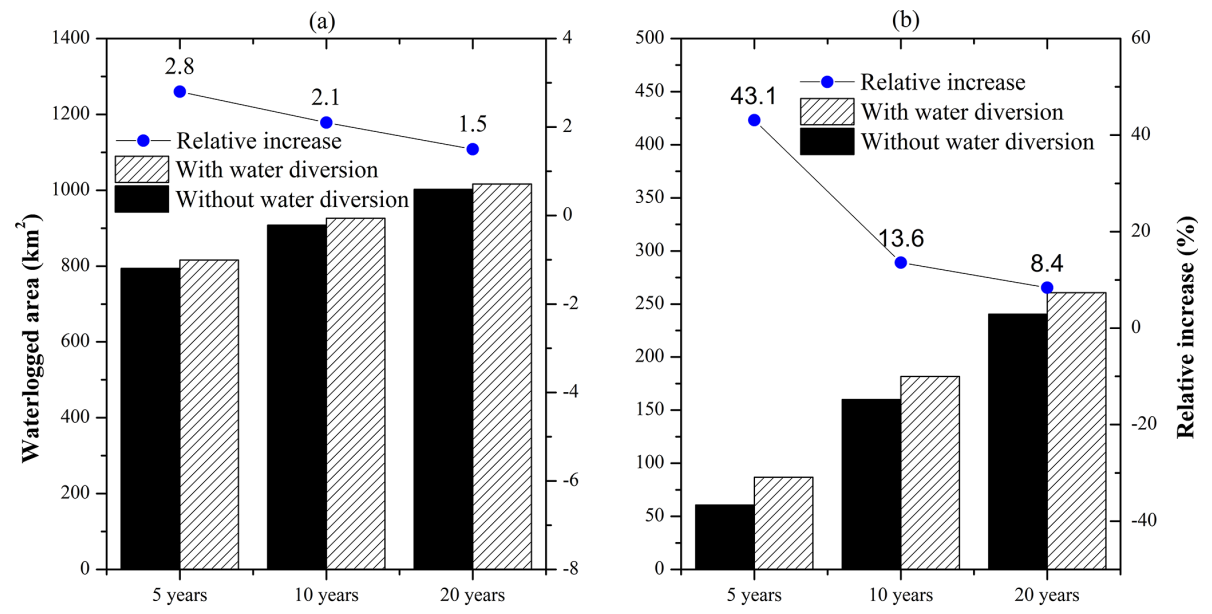

Figure 8. Changes in waterlogging areas in the lakeside area under the influence of water diversion (shaded bar) and no diversion (black bar). The black line represents the trend of the relative increase in waterlogged area caused by water diversion.
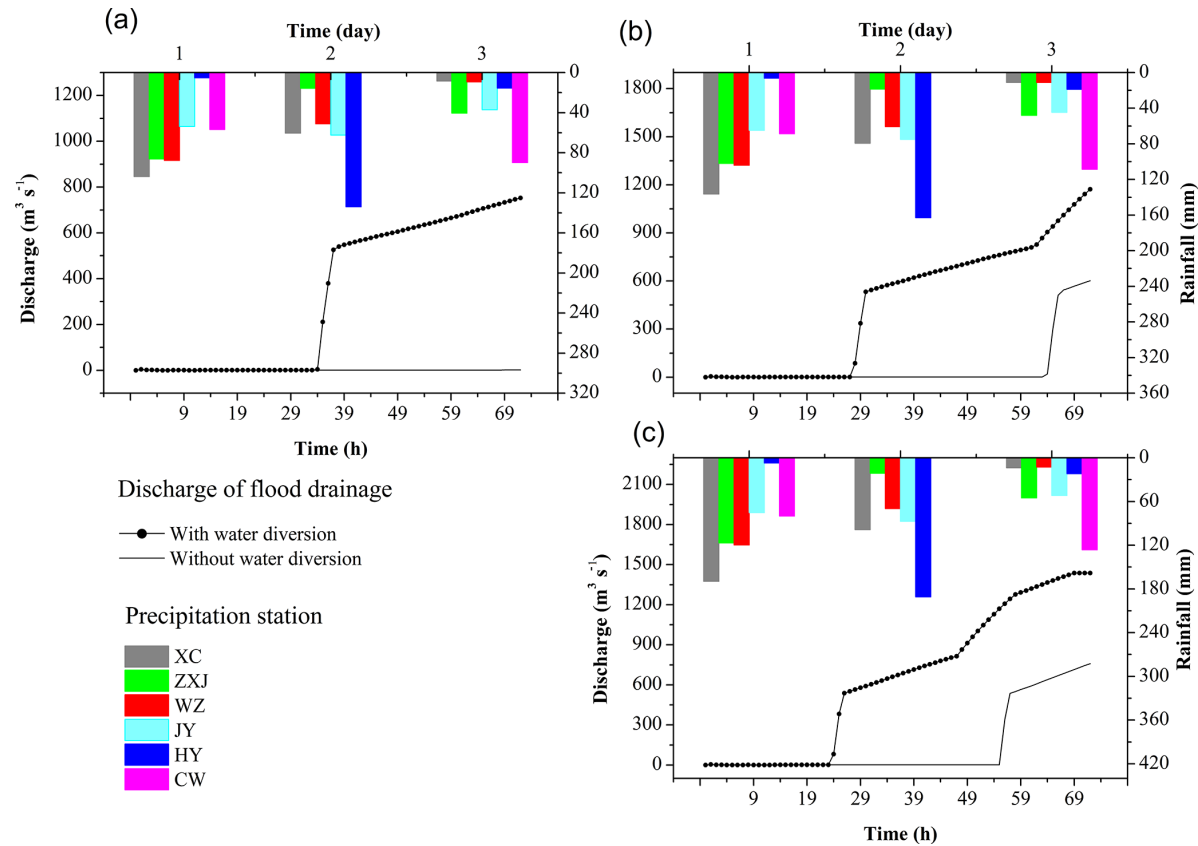

Figure 9. Changes in the flood discharge of the ED under water diversion with different storm levels. Flood discharge under rainfall events for different return periods: 5 years (a), 10 years (b), 20 years (c). The bar chart with different colours shows the 3-day rainfall processes at each rainfall station. Black lines represent the flood-discharge process of the ED with and without the effect of water diversion.

water diversion has a more obvious effect on waterlogging areas, with an inundated water depth above $0.5 \mathrm{~m}$, and the area increasing by $8.4 \%-43.1 \%$. The total volume of flooding discharged by the ED also increased. In addition, we found that with the increase in rainfall intensity, the influence of water diversion on the lakeside area in the NL-inundated area gradually decreased and the water transfer had more serious effects during rainstorms with lower return periods.
Certain implications for the management of inter-basin water diversion and lake basins along the route of the water diversion project are presented below.

1. For a complicated flood control and drainage system that contains a number of hydraulic structures, such as pumping stations, sluices, and embankments, flood movement behaviour regulations must be implemented and flood disaster losses must be reduced by establishing one- and two-dimensional coupled hydrodynamic 
models to accurately simulate the flow process and a clear movement direction of floods.

2. For a long-distance inter-basin water transfer project, due to the large difference between high and low precipitation in water supply and water-receiving areas (combined with global climate change and hydrological uncertainty), strengthening the analysis of the emergency water diversion influence on flood control and drainage is not only necessary for the scientific management of the inter-basin water transfer project, but also conducive to realizing the expected benefits and reducing the negative effects of the project.

3. To reduce the inter-basin water transfer project effect on waterlogging in the water-receiving area, we can take steps based on the following factors. First, additional emphasis should be placed on planning projects, increasing the number of waterlogging drainage pumping stations and enlarging the capacity of flood discharge buildings in water-receiving basins. Second, hydrological forecasting and early warning abilities should be improved and the accuracy and forecast period of rainfall events should be increased to stop water diversion or lower the water level of the lake before the rainstorm.

Regarding future research, we can expand on the following aspects: (1) the vulnerability of hazard-affected bodies, populations, gross domestic product (GDP), and other information should be considered to more accurately reflect waterlogging disasters in the research area; (2) a case study analysis of the balance between water transfer risk and water resource benefits should be conducted; and (3) in the future, the spatial distribution of roughness in NL should be considered to improve the accuracy of flood simulation in NL.

Data availability. All data except for the DEM of the lakeside and Nansihu Lake in 2013 were acquired by the authors. Data except for the DEM can be requested by email from the author at wangzz77@163.com.

Author contributions. KW prepared the manuscript with contributions from all the co-authors. KW and ZW developed the model and ZW designed the scenario. KL, LC, and LW guided and participated in the modelling; KL and LC dealt with the boundary conditions of the model. AY made the electric artworks and did the word processing.

Competing interests. The authors declare that they have no conflict of interest.

Acknowledgements. This study was financially supported by the National Key Research and Development Program of China
(2017YFC0403504) and the National Science Foundation of China under grant nos. 51479119 and 51579064.

Edited by: Heidi Kreibich

Reviewed by: Christian Siebert and one anonymous referee

\section{References}

Abbott, M. B.: Computational Hydraulics, Pitman, London, 1979.

An, W. C. and Li, X. M.: Phosphate adsorption characteristics at the sediment - water interface and phosphorus fractions in Nansi Lake, China, and its main inflow rivers, Environ. Monit. Assess., 173-184, https://doi.org/10.1007/s10661-007-0149-6, 2009.

Aron, G., White, E. L., and Coelen, S. P.: Feasibility of Interbasin Water Transfer, J. Am. Water Resour. Assoc., 13, 1021-1034, https://doi.org/10.1111/j.1752-1688.1977.tb03867.x, 1977.

Arrighi, C., Brugioni, M., Castelli, F., Franceschini, S., and Mazzanti, B.: Urban micro-scale flood risk estimation with parsimonious hydraulic modelling and census data, Nat. Hazards Earth Syst. Sci., 13, 1375-1391, https://doi.org/10.5194/nhess13-1375-2013, 2013.

Bisht, D. S., Chatterjee, C., Kalakoti, S., Upadhyay, P., Sahoo, M., and Panda, A.: Modeling urban floods and drainage using SWMM and MIKE URBAN: a case study, Nat. Hazards, 84, 749-776, https://doi.org/10.1007/s11069-016-2455-1, 2016.

Boussinesq, J. V.: Théorie des ondes et des remous qui se propagent le long d'un canal rectangulaire horizontal, encommuniquant au liquide contenu dans ce canal des vitesses sensiblement pareilles de la surface au fond, Mathématiques Pures et Appliquées, 17, 55-108, 1872.

Bureau of South to North Water Transfer of Planning, Designing and Management, Ministry of Water Resources: Brief Introduction of General Planning for South-to-North Water Transfer Project, China Water Resources, 11-13 + 18, 2003 (in Chinese).

Cai, X. and Ringler, C.: Balancing agricultural and environmental water needs in China: Alternative scenarios and policy options, Water Policy, 9, 95-108, https://doi.org/10.2166/wp.2007.047, 2007.

Cole, D. S., Carver, W. B., Hall, B. S., and Slover, P. C.: Interbasin Transfers of Water, Proc. 2011 Georg. Water Resour. Conf., available at: http://www.gwri.gatech.edu/sites/default/files/files/ docs/2011/3.5.4Cole.pdf (last access: 10 March 2019), 2011.

Davies, B. R., Thoms, M., and Meador, M.: An assessment of the ecological impacts of inter-basin water transfers, and their threats to river basin integrity and conservation, Aquat. Conserv. Mar. Freshw. Ecosyst., 2, 325-349, https://doi.org/10.1002/aqc.3270020404, 1992.

de Andrade, J. G. P., Barbosa, P. S. F., Souza, L. C. A., and Makino, D. L.: Interbasin Water Transfers: The Brazilian Experience and International Case Comparisons, Water Resour. Manag., 25, 1915-1934, https://doi.org/10.1007/s11269-011-9781-6, 2011.

Dixon, B. and Earls, J.: Effects of urbanization on streamflow using SWAT with real and simulated meteorological data, Appl. Geogr., 35, 174-190, 2012.

Dotto, C. B. S., Kleidorfer, M., Deletic, A., Rauch, W., Mccarthy, D. T., and Fletcher, T. D.: Performance and sensitivity analysis of stormwater models using a Bayesian approach and long-term 
high resolution data, Environ. Model. Softw., 26, 1225-1239, 2011.

Dutta, D., Herath, S., and Musiake, K.: Flood inundation simulation in a river basin using a physically based distributed hydrologic model, Hydrol. Process., 14, 497-519, 2015.

Emanuel, R. E., Buckley, J. J., Caldwell, P. V., McNulty, S. G., and Sun, G.: Influence of basin characteristics on the effectiveness and downstream reach of interbasin water transfers: Displacing a problem, Environ. Res. Lett., 10, 12, https://doi.org/10.1038/s41598-017-06225-9, 2015.

Guo, Y., Liu S., and Liang, X. Y.: Study on Emergency Water Supply Scheme for North Extension of Eastern Route of South-toNorth Water Transfer Project, Haihe Water Resour., 3, 1-3, 2018 (in Chinese).

Gupta, J. and Van Der Zaag, P.: Interbasin water transfers and integrated water resources management?: Where engineering, science and politics interlock, Phys. Chem. Earth, 33, 28-40, https://doi.org/10.1016/j.pce.2007.04.003, 2008.

Hamel, P. and Fletcher, T. D.: Modelling the impact of stormwater source control infiltration techniques on catchment baseflow, Hydrol. Process., 28, 5817-5831, https://doi.org/10.1002/hyp.10069, 2014.

He, B., Huang, X., Ma, M., Chang, Q., Tu, Y., Li, Q., Zhang, K., and Hong, Y.: Analysis of flash flood disaster characteristics in China from 2011 to 2015, Nat. Hazards, 90, 407-420, https://doi.org/10.1007/s11069-017-3052-7, 2018a.

Hsu, M. H., Chen, S. H., and Chang, T. J.: Inundation simulation for urban drainage basin with storm sewer system, J. Hydrol., 234, 21-37, https://doi.org/10.1016/S0022-1694(00)00237-7, 2000.

$\mathrm{Hu}$, S., Wang, Z., Wang, Y., and Zhang, L.: Total control-based unified allocation model for allowable basin water withdrawal and sewage discharge, Sci. China Technol. Sci., 53, 138-1397, https://doi.org/10.1007/s11431-010-0155-8, 2010.

$\mathrm{Hu}$, W., Zhai, S., Zhu, Z., and Han, H.: Impacts of the Yangtze River water transfer on the restoration of Lake Taihu, Ecol. Eng., 34, 30-49, 2008.

ICID: Experiences in inter-basin water transfers for irrigation, drainage or flood management, Unpublished report, International Commission on Irrigation and Drainage ICID-CIID, New Delhi, available at: http://www.icid.org/ibwt_draft_aug05.pdf (last access: 20 October 2016), 15 August 2005.

Karamouz, M., Mojahedi, S. A., and Ahmadi, A.: Interbasin water transfer: economic water quality-based model, J. Irrig. Drain. Eng., 136, 90-98, 2010.

Karim, F., Petheram, C., Marvanek, S., Ticehurst, C., Wallace, J., and Hasan, M.: Impact of climate change on floodplain inundation and hydrological connectivity between wetlands and rivers in a tropical river catchment, Hydrol. Process., 30, 1574-1593, 2016.

Khan, M. A., Vangani, N. S., Singh, N., and Singh, S.: Environmental Impact of Indira Gandhi Canal Project in Rawatsar Tehsil of Hanumangarh District, Rajasthan, Ann. Arid Zone, 38, 137-144, 1999.

Kundell, J. E.: Interbasin water tansfers in riparian states: A case study of Georgia, J. Am. Water Resour. Assoc., 24, 87-94, 1988.

Larson, K. J., Başagaoglu, H., and Mariño, M. A.: Prediction of optimal safe ground water yield and land subsidence in the Los Banos-Kettleman City area, California, using a calibrated numerical simulation model, J. Hydrol., 242, 79-102, 2001.
Lee, J. G. and Heaney, J. P.: Estimation of Urban Imperviousness and its Impacts on Storm Water Systems, J. Water Resour. Plan. Manag., 129, 419-426, 2003.

Li, W., Xu, B., and Wen, J.: Scenario-based community flood risk assessment: a case study of Taining county town, Fujian province, China, Nat. Hazards, 82, 193-208, https://doi.org/10.1007/s11069-016-2187-2, 2016.

Liang, Y. S., Wang, W., Li, H. J., Shen, X. H., Xu, Y. L., and Dai, J. R.: The South-to-North Water Diversion Project: Effect of the water diversion pattern on transmission of Oncomelania hupensis, the intermediate host of Schistosoma japonicum in China, Parasites and Vectors, 5, 52, https://doi.org/10.1186/1756-33055-52, 2012

Liu, C. and Zheng, H.: South-to-north water transfer schemes for China, Int. J. Water Resour. Dev., 18, 453-471, https://doi.org/10.1080/0790062022000006934, 2002.

Liu, Q., Qin, Y., Zhang, Y., and Li, Z.: A coupled 1D-2D hydrodynamic model for flood simulation in flood detention basin, Nat. Hazards, 75, 1303-1325, https://doi.org/10.1007/11069014-1373-3, 2015.

Liu, R., Liu, S. C., Cicerone, R. J., Shiu, C. J., Li, J., Wang, J., and Zhang, Y.: Trends of extreme precipitation in eastern China and their possible causes, Adv. Atmos. Sci., 32, 1027-1037, https://doi.org/10.1007/s00376-015-5002-1, 2015.

Ma, J., Hoekstra, A. Y., Wang, H., Chapagain, A. K., and Wang, D.: Virtual versus real water transfers within China, Philos. T. R. Soc. B, 361, 835-842, https://doi.org/10.1098/rstb.2005.1644, 2006.

Matete, M. and Hassan, R.: Integrated ecological economics accounting approach to evaluation of interbasin water transfers: An application to the Lesotho Highlands Water Project, Ecol. Econ., 60, 246-259, https://doi.org/10.1016/j.ecolecon.2005.12.010, 2006.

Moel, H. De, Jongman, B., Kreibich, H., Merz, B., PenningRowsell, E., and Ward, P. J.: Flood risk assessments at different spatial scales, Mitig. Adapt. Strateg. Glob. Chang., 20, 865-890, 2015.

Nash, J. E. and Sutcliffe, J. V.: River flow forecasting through conceptual models Part I - A discussion of principles, J. Hydrol., 10, 282-290, 1970.

Quan, R. S.: Rainstorm waterlogging risk assessment in central urban area of Shanghai based on multiple scenario simulation, Nat. Hazards, 73, 1569-1585, https://doi.org/10.1007/s11069014-1156-x, 2014.

Rasmussen, P. W., Schrank, C., and Williams, M. C. W.: Trends of PCB concentrations in Lake Michigan coho and chinook salmon, 1975-2010, J. Great Lakes Res., 40, 748-754, 2014.

Sun, D. P., Xue, H., Wang, P. T., Lu, R. L., and Liao, X. L.: 2D Numerical Simulation of Flooding Effects Caused by Southto-North Water Transfer Project, J. Hydrodyn., 20, 662-667, https://doi.org/10.1016/S1001-6058(08)60110-9, 2008.

Tang, C., Yi, Y., Yang, Z., and Cheng, X.: Water pollution risk simulation and prediction in the main canal of the Southto-North Water Transfer Project, J. Hydrol., 519, 2111-2120, https://doi.org/10.1016/j.jhydrol.2014.10.010, 2014.

Tian, C., Pei, H., Hu, W., and Xie, J.: Phytoplankton variation and its relationship with the environmental factors in Nansi Lake, China, Environ. Monit. Assess., 185, 295-310, https://doi.org/10.1007/s10661-012-2554-8, 2013. 
Vrebos, D., Vansteenkiste, T., Staes, J., Willems, P., and Meire, P.: Water displacement by sewer infrastructure in the Grote Nete catchment, Belgium, and its hydrological regime effects, Hydrol. Earth Syst. Sci., 18, 1119-1136, https://doi.org/10.5194/hess-181119-2014, 2014.

Wang, H., Steyer, G. D., Couvillion, B. R., Rybczyk, J. M., Beck, H. J., Sleavin, W. J., Meselhe, E. A., Allison, M. A., Boustany, R. G., and Fischenich, C. J.: Forecasting landscape effects of Mississippi River diversions on elevation and accretion in Louisiana deltaic wetlands under future environmental uncertainty scenarios, Estuar. Coast. Shelf Sci., 138, 57-68, 2014.

Wang, L., Gan, H., Wang, F., Sun, X., and Zhu, Q.: Characteristic analysis of plants for the removal of nutrients from a constructed wetland using reclaimed water, Clean-Soil Air Water, 38, 35-43, https://doi.org/10.1002/clen.200900162, 2010.

Wang, L., Yan, D., Wang, H., Yin, J., and Bai, Y.: Impact of the Yalong-Yellow River water transfer project on the ecoenvironment in Yalong River basin, Sci. China Technol. Sci., 56, 831-842, https://doi.org/10.1007/s11431-013-5155-z, 2013.

Wang, Y.: Waterlogging disaster and its treatment in huai river basin. Science Press, in: Brief Introduction of Special Experiments on Typical Crops Submerged in Huaihe River Basin China, edited by: Peng, S. and Tian, X., Science Press, Beijing, 94-141, 2015 (in Chinese).

Wang, Z., Wu, J., Cheng, L., Liu, K., and Wei, Y.-M.: Regional flood risk assessment via coupled fuzzy c-means clustering methods: an empirical analysis from China's Huaihe River Basin, Nat. Hazards, 93, 1-20, https://doi.org/10.1007/s11069-018-3325-9, 2018.

Webber, M., Crow-Miller, B., and Rogers, S.: The South-North Water Transfer Project: remaking the geography of China, Reg. Stud., 51, 370-382, https://doi.org/10.1080/00343404.2016.1265647, 2017.

Welch, E. B., Barbiero, R. P., Bouchard, D., and Jones, C. A.: Lake trophic state change and constant algal composition following dilution and diversion, Ecol. Eng., 1, 173-197, 1992.
Wu, Z., Zhang, J., Zhu, J., Ren, J., and Chen, S.: A monitoring project planning technique of the water quality spatial distribution in Nansi lake, Procedia Environ. Sci., 10, 2320-2328, https://doi.org/10.1016/j.proenv.2011.09.362, 2011.

Ye, A., Duan, Q., Chu, W., Xu, J., and Mao, Y.: The impact of the south-north water transfer project (CTP)'s central route on groundwater table in the Hai River basin, north China, Hydrol. Process., 28, 5755-5768, https://doi.org/10.1002/hyp.10081, 2014.

Zhai, S., Hu, W., and Zhu, Z.: Ecological impacts of water transfers on Lake Taihu from the Yangtze River, China, Ecol. Eng., 36, 406-420, 2010.

Zhang, L., Li, S., Loáiciga, H. A., Zhuang, Y., and Du, Y.: Opportunities and challenges of interbasin water transfers: a literature review with bibliometric analysis, Scientometrics, 105, 279-294, https://doi.org/10.1007/s11192-015-1656-9, 2015.

Zhang, Q.: The South-to-North Water Transfer Project of China: Environmental implications and monitoring strategy, J. Am. Water Resour. Assoc., 45, 1238-1247, https://doi.org/10.1111/j.1752-1688.2009.00357.x, 2009.

Zhao, Z. Y., Zuo, J., and Zillante, G.: Transformation of water resource management: a case study of the South-toNorth Water Diversion project, J. Clean. Prod., 163, 136-145, https://doi.org/10.1016/j.jclepro.2015.08.066, 2017.

Zhuang, W.: Eco-environmental impact of inter-basin water transfer projects: a review, Environ. Sci. Pollut. Res., 23, 12867-12879, https://doi.org/10.1007/s11356-016-6854-3, 2016.

Zolghadr, M., Hashemi, M. R., and Hosseinipour, E. Z.: Modeling of flood wave propagation through levee breach using MIKE21, a case study in Helleh River, Iran, in: Proceedings of American Society of Civil Engineers World Environmental and Water Resources Congress 2010, Providence, Rhode Island, United States, 16-20, 2683-2693, 2010. 